\title{
KAJIAN UPAH PEKERJA KONSTRUKSI PADA PROYEK BANGUNAN GEDUNG DI PROVINSI SUMATERA BARAT
}

\author{
FEBRIMEN HERISTA, ANA SUSANTI YUSMAN \\ Fakultas Teknik, Universitas Muhammadiyah Sumatera Barat \\ febrimen69@gmail.com, santi.nurdin@gmail.com
}

\begin{abstract}
In the world of the construction industry, the wages of workers are quite large, which is about one-third of the construction value. So the company should pay serious attention to the wages of these workers. However, information regarding the wages of construction workers is only in the form of daily wages for casual workers and monthly wages for permanent workers, while information on the cost of workers' costs is not available. This study aims to identify the components of labor costs and their proportion to the overall cost of construction workers wages and to identify factors related to wages and costs of construction workers. In this study the method used is empirical and inductive methods, then the data obtained is processed and analyzed using descriptive statistics and comparative analysis. To model the burden of labor costs into its components and their respective proportions, descriptive statistical methods are used, while to analyze the variables -variables that affect wages and costs of workers used comparative analysis method. From the results of data processing, conclusions are drawn using the inductive method as follows: 1) The costs of workers are grouped into direct and indirect costs, and conditional costs, but the distribution of each cost component between permanent workers and freelancers is different; 2) Company profile, project profile, and worker profile. have an effect on wages and costs of construction workers.
\end{abstract}

Keywords: Construction worker's wages, Constrction labor burden, Construction workers

\begin{abstract}
Abstrak: Dalam dunia industri konstruksi, upah pekerja cukup besar porsinya yaitu sekitar 30\% dalam nilai konstruksi. Maka perusahaan harus memberikan perhatian serius terhadap upah pekerja ini.Tapi informasi mengenai upah pekerja konstruksi hanya berupa upah harian untuk pekerja lepas dan upah bulanan untuk pekerja tetap, sedangkan informasi beban biaya pekerja tidak tersedia. Penelitian ini bertujuan untuk mengidentifikasi komponen beban biaya pekerja dan proporsinya terhadap keseluruhan biaya upah pekerja konstruksi dan untuk mengidentifikasi faktor yang berhubungan dengan upah dan beban biaya pekerja konstruksi. Pada penelitian ini metode yang digunakan adalah metode empiris dan induktif. Selanjutnya data yang yang diperoleh diolah dan dianalisis menggunakan statistik deskriptif dan analisis perbandingan.Untuk memodelkan beban biaya pekerja menjadi komponen-komponennya beserta proporsi masing-masing digunakan metoda statistik deskriptif,sedangkan untuk menganalisis variabel-variabel yang berpengaruh terhadap upah dan beban biaya pekerja digunakan metoda analisis perbandingan. Dari hasil pengolahan data, disusun kesimpulan dengan metode induktif sebagai berikut: 1) Beban biaya pekerja dikelompokkan menjadi biaya secara langsung dan tidak langsung, dan yang bersifat kondisional, tapi distribusi masing-masing komponen biayanya antara pekerja tetap dan pekerja lepas berbeda; 2) Profil perusahaan, profil proyek, dan profilpekerja.berpengaruh pada upah dan beban biaya pekerja konstruksi.
\end{abstract}


Kata Kunci: Upah pekerja konstruksi, Beban biaya pekerja konstruksi, Pekerja konstruksi.

\section{A. Pendahuluan}

Secara singkat upah merupakan kompensasi yang dperoleh pekerja atas pekerjaan yang telah dilakukannya. Dinamika besaran upah pekerja konstruksi dalam beberapa tahun terakhir dari hasil survei Badan Pusat Statistik, dapat dilihat pada Tabel 1. Kompensasi pekerja konstruksi saat ini masih berupa upah harian untuk pekerja lepas dan upah bulanan untuk pekerja tetap. Padahal masih ada biaya lain yang didefinisikan sebagai beban biaya pekerja yang informasi masih belum tersedia di Indonesia, berbeda dengan negara-negara maju, seperti Amerika Serikat dan negara di Eropa yang telah mampu memodelkan beban biaya pekerja konstruksi menjadi komponen penyusunnya beserta besarannya

Di Indonesia informasi mengenai beban biaya pekerja konstruksi masih terbatas, yang berakibat pada sulitnya mengestimasi biaya pekerja konstruksi secara akurat dan akan berpengaruh pada ketidakadaan informasi mengenai kontribusi biaya upah terhadap nilai tambah produkkonstruksi itu sendiri. Perusahaan Kontraktor menurut peraturan LPJKN No. 10 Tahun 2013 tentang Registrasi Usaha Jasa Pelaksana Konstruksi menyebutkan dengan istilah usaha jasa pelaksana konstruksi dan mendefinisikan sebagai jenis usaha jasa konstruksi yang menyediakan layanan jasa pelaksanaan pekerjaan konstruksi, yang dibedakan menurut bentuk usaha, klasifikasi, dan kualifikasi usaha jasa pelaksana konstruksi. Dalam menjalankan kewajibannya, pekerja mempunyai hak berupa upah merupakan yang diterima dan biasanya dinyatakan dalam bentuk uang dari pengusaha atau pemberi kerja yang ditetapkan dan dibayarkan menurut suatu perjanjian kerja, kesepakatan atau peraturan perundangundangan (Pasa 11 UU No. 13 Tahun 2003 tentang Ketenagakerjaan).

Perusahaan harus menanggung tunjangan/biaya- biaya lain yang berhubungan dengan pekerja diluar upah pokoknya. Namun informasi mengenai struktur upah pekerja konstruksi di Indonesia saat ini masih berupa gaji bulanan untuk pekerja tetap dan upah harian untuk pekerja lepas. Beban biaya pekerja besaranya berbeda antara satu dengan yang lain, berdasarkan pada umur, tanggungan atau kepemilikan di perusahaan (Hedley, 2007). Jenis pekerjaan juga mempengaruhi tingkat beban biaya pekerja (Rabinaw, 2006).

\begin{tabular}{|c|c|c|c|c|c|c|c|c|}
\hline No. & Rincian & $\begin{array}{c}\text { Satua } \\
\text { n }\end{array}$ & 2013 & 2014 & 2015 & 2016 & 2017 & $\begin{array}{r}\text { Rata- } \\
\text { rata }\end{array}$ \\
\hline A. & \multicolumn{8}{|c|}{ Pekerja Tetap } \\
\hline 1 & $\begin{array}{l}\text { Balasjasa } \\
\text { pekerja } \\
\text { tetap } \\
\text { konstruksi }\end{array}$ & $10^{6} \mathrm{Rp}$ & 224.920 & 237.674 & 245.609 & 254.072 & 270.802 & $246.615,4$ \\
\hline 2 & $\begin{array}{l}\text { Pertumbuhan } \\
\text { balas jasa (y- } \\
\text { o-y) }\end{array}$ & $\%$ & 6,81 & 5,67 & 3,34 & 3,45 & 6,58 & 5,17 \\
\hline 3 & $\begin{array}{l}\text { Rata-rata balas } \\
\text { jasa }\end{array}$ & $10^{3} \mathrm{Rp}$ & 26.360 & 26.927 & 27.449 & 27.981 & 29.175 & $27.578,4$ \\
\hline 4 & $\begin{array}{l}\text { Pertumbuh } \\
\text { an rata-rata } \\
\text { balas } \\
\text { jasa (y-o-y) }\end{array}$ & $\%$ & 5,35 & 2,15 & 1,94 & 1,94 & 4,27 & 3,13 \\
\hline B. & & & & ri & & & & \\
\hline
\end{tabular}




\begin{tabular}{|c|c|c|c|c|c|c|c|c|}
\hline 1 & $\begin{array}{l}\text { Upah pekerja } \\
\text { harian } \\
\text { konstruksi }\end{array}$ & $10^{6} \mathrm{Rp}$ & 865.209 & 968.725 & $\begin{array}{c}1.078 .61 \\
7\end{array}$ & 1.182 .934 & $\begin{array}{c}1.312 .72 \\
5\end{array}$ & 1.081 .642 \\
\hline 2 & $\begin{array}{l}\text { Pertumbuh } \\
\text { an upah (y- } \\
\text { o-y) }\end{array}$ & $\%$ & 1,11 & 1,06 & 1,04 & 1,01 & 0,98 & 1,04 \\
\hline 3 & Rata-rata upah & $\mathrm{Rp}$ & 85.545 & 88.535 & 92.760 & 95.118 & 97.288 & $91.849,2$ \\
\hline 4 & $\begin{array}{l}\text { Pertumbuhan } \\
\text { rata-rata } \\
\text { upah (y-o- } \\
\text { y) }\end{array}$ & $\%$ & 1,84 & 3,49 & 4,77 & 2,54 & 3,11 & 3,15 \\
\hline
\end{tabular}

Sumber: Benchmark statistik konstruksi 2012-2017 oleh Badan Pusat Statistik

\section{B. Metodologi Penelitian}

Dapat disimpulkan bahwa pembebanan biaya pekerja konstruksi sangat penting artinya dalam rangka mengetahui hubungan antara komponen-komponen biaya upah terhadap nilai tambah produk konstruksi. Untuk mencapai hal tersebut, perlu disusun suatu rancangan penelitian yang bertujuanantara lain: 1) Mengidentifikasi komponen beban biaya pekerja dan proporsinya terhadap keseluruhan biaya upah pekerja konstruksi; dan 2) Mengidentifikasi faktor yang berhubungan dengan upah dan beban biaya pekerja konstruksi. Penelitian ini dibatasi hanya untuk hal-hal sebagai berikut: 1) .Sampel utama pada penelitian ini adalah pekerja pada proyek gedung yang dilaksanakan oleh perusahaan kontraktor gredbesar; dan 2) .Lokasi studi difokuskan di Provinsi Sumatera Barat Dalam penelitian ini metode yang digunakan adalah gabungan antara metode empiris dengan metode induktif. Metode empiris digunakan dengan cara survey langsung ke lapangan guna memperoleh informasi objektif berupa upah pekerja. Data yang telah terkumpul selanjutnya diolah dan dianalisis menggunakan statistik deskriptif dananalisis perbandingan. Metode statistik deskriptif digunakan untuk memodelkan beban biaya pekerja menjadi komponen beserta persentase masing-masing.

\section{Hasil Dan Pembahasan}

Responden pada penelitian ini adalah proyek konstruksi gedung yang dikerjakan oleh perusahaan kontraktor gred besar beserta pekerja tetap dan pekerja lepasnya. Namun terdapat perkembangan pada saat prosespengumpulan data, di mana responden yangdiperoleh tidak hanya berasal dari kontraktor gred besar saja namun juga dari gred menengah. Responden ini tersebar di berbagai kota, jenis perusahaan, kualifikasi perusahaan, durasi proyek, nilai kontrak proyek.

Berdasarkan hasil pengumpulan data, terlihat responden yang diperoleh lebih banyak berasal dari perusahaan kontraktor swasta nasional. Hal inidisebabkan karena jumlah kontraktor BUMN di Indonesia jauh lebih sedikit.Dan terlihat juga bahwa mayoritas proyek besar di Indonesia membutuhkan waktu pelaksanaan multi years. Untuk responden pekerja, hierarki umumnya seperti yang tercantum pada Tabel 1. Dapat dilihat bahwa secara umum, pekerja konstruksi terbagi menjadi 2 jenis, yaitu pekerja tetap dan pekerja lepas. 
Tabel 1. Responden proyek berdasarkan lokasi

\begin{tabular}{|c|l|c|c|}
\hline No & Kota & Jumlah proyek & Persentase \\
\hline 1 & Padang & 6 & $33,33 \%$ \\
\hline 2 & Bukitinggi & 4 & $22,22 \%$ \\
\hline 3 & Padang Panjang & 3 & $16,67 \%$ \\
\hline 4 & Painan & 2 & $11,11 \%$ \\
\hline 5 & Pariaman & 3 & $16,67 \%$ \\
\hline & Total & 18 & $100 \%$ \\
\hline
\end{tabular}

Tabel 2. Responden proyek berdasarkan jenis perusahaan

\begin{tabular}{|c|c|c|c|}
\hline No & Jenis perusahaan & Jumlah proyek & Persentase \\
\hline 1 & BUMN & 6 & $33,33 \%$ \\
\hline 2 & Swasta Nasional & 12 & $66,67 \%$ \\
\hline & Total & 18 & $100 \%$ \\
\hline
\end{tabular}

Tabel 3.Responden proyek berdasarkan kualifikasi perusahaan

\begin{tabular}{|c|c|c|c|}
\hline No & Kualifikasi perusahaan & Jumlah provek & Persentase \\
\hline 1 & M1 & 2 & $11,11 \%$ \\
\hline 2 & M2 & 3 & $16,67 \%$ \\
\hline 3 & B1 & 3 & $16,67 \%$ \\
\hline 4 & B2 & 10 & $55,56 \%$ \\
\hline & Total & 18 & $100 \%$ \\
\hline
\end{tabular}

Tabel 4. Responden proyek berdasarkan durasi

\begin{tabular}{|c|c|c|c|}
\hline No & Durasi & Jumlah proyek & Persentase \\
\hline 1 & $<1$ tahun & 3 & $16,67 \%$ \\
\hline 2 & $1-2$ tabun & 13 & $72,22 \%$ \\
\hline 3 & $2-3$ tahun & 2 & $11,11 \%$ \\
\hline & Total & 18 & $100 \%$ \\
\hline
\end{tabular}

Tabel 5. Responden proyek berdasarkan nilai kontrak

\begin{tabular}{|c|c|c|c|}
\hline No & Nilai kontrak & Jumlah proyek & Persentase \\
\hline 1 & $1-25 \mathrm{M}$ & 5 & $27,78 \%$ \\
\hline 2 & $26-30 \mathrm{M}$ & 4 & $22,22 \%$ \\
\hline 3 & $51-75 \mathrm{M}$ & 3 & $16,67 \%$ \\
\hline 4 & $76-100 \mathrm{M}$ & 2 & $11,11 \%$ \\
\hline 5 & $101-125 \mathrm{M}$ & 2 & $11,11 \%$ \\
\hline 6 & $>125 \mathrm{M}$ & 2 & $11,11 \%$ \\
\hline & Total & 23 & $100 \%$ \\
\hline
\end{tabular}


Tabel 6. Responden pekerja berdasarkan jenisnya

\begin{tabular}{|c|c|c|c|c|}
\hline No & $\begin{array}{c}\text { Jenis } \\
\text { pekeria }\end{array}$ & $\begin{array}{c}\text { Kualifikasi } \\
\text { perusahaan }\end{array}$ & Total & Persentase \\
\hline & M1 & M2 & 11 & \\
\hline 1 & Tetap & B1 & 17 & $35,07 \%$ \\
\hline & & B2 & 71 & \\
\hline & Jumlah & 121 & \\
\hline & M1 & 27 & \\
\hline 2 & M2 & 30 & \\
\hline & Lepas & B1 & 38 & $64,93 \%$ \\
\hline & & B2 & 129 & \\
\hline & & Jumlah & 224 & \\
\hline & & & 345 & $100 \%$ \\
\hline
\end{tabular}

Tabel 7. Responden pekerjatetap pada posisikantor

\begin{tabular}{|c|c|c|c|c|c|}
\hline \multirow{2}{*}{ Jabatan } & \multicolumn{4}{|c|}{ Kualifikasi perusahaan } & \multirow[b]{2}{*}{ Total } \\
\hline & MI & M2 & B1 & B2 & \\
\hline PM & $\mathrm{T}$ & & & 2 & 3 \\
\hline SEM & & & & 1 & $\mathrm{~T}$ \\
\hline SAM & & & $\mathrm{T}$ & 2 & 3 \\
\hline QS & $\mathrm{T}$ & $\mathrm{T}$ & 3 & 3 & 10 \\
\hline Engineer & 4 & $\mathrm{~T}$ & 5 & 19 & 29 \\
\hline Logistik & 2 & 1 & $\mathrm{~T}$ & 5 & 9 \\
\hline Admin & 2 & 1 & & 3 & 6 \\
\hline Komersial & 1 & & & 1 & 2 \\
\hline Drafter & 3 & 2 & $\mathrm{~T}$ & 7 & 13 \\
\hline Gudang & & & 1 & 1 & 2 \\
\hline Total & 14 & 6 & 12 & 46 & 78 \\
\hline
\end{tabular}

Tabel 8. Responden pekerja tetap pada posisi lapangan

\begin{tabular}{|c|c|c|c|c|c|}
\hline \multirow{2}{*}{ Jabatan } & \multicolumn{4}{|c|}{ Kualifikasi perusahaan } & \multirow{2}{*}{ Total } \\
\hline & MI & M2 & B1 & B2 & \\
\hline $\mathrm{QC}$ & $\mathrm{r}$ & & & 2 & 3 \\
\hline SHE & & & 1 & 2 & 3 \\
\hline SOM & $\mathrm{r}$ & 1 & $r$ & $\mathrm{r}$ & 4 \\
\hline GSP & 1 & $\mathrm{r}$ & & 3 & 5 \\
\hline Surveyor & 1 & & 1 & 8 & 10 \\
\hline SP & 2 & 1 & 1 & 4 & 8 \\
\hline Ass. Sunveyor & & & $\mathrm{T}$ & 1 & 2 \\
\hline Total & 6 & 3 & 5 & 21 & 35 \\
\hline
\end{tabular}


Perolehan responden pekerja lepas dapat dilihat pada Tabel 9 sebagai berikut:

\begin{tabular}{|c|c|c|c|c|c|c|c|c|}
\hline \multirow{2}{*}{$\begin{array}{l}\text { Kualifikasi } \\
\text { Perusahaan }\end{array}$} & \multicolumn{2}{|c|}{ M1 } & \multicolumn{2}{|l|}{ M2 } & \multirow{2}{*}{$\frac{\text { B1 }}{T^{-}}$} & \multicolumn{2}{|l|}{ B2 } & \multirow[b]{2}{*}{ Total } \\
\hline & $\mathbf{T}$ & $\mathbf{L}$ & $\mathbf{T}$ & L & & $\mathbf{T}$ & L & \\
\hline \multicolumn{9}{|l|}{ Arsitektur } \\
\hline Pasang bata/hebel & 6 & 3 & 2 & 1 & 5 & 13 & 6 & 39 \\
\hline Plester + aci & 1 & 1 & 2 & & 5 & -3 & 1 & 15 \\
\hline Keramik & & & 3 & & 4 & 2 & & 9 \\
\hline Bjaton & 3 & 2 & & & $\mathrm{~T}$ & 3 & & 9 \\
\hline Cat & & & & & 2 & 5 & 2 & 13 \\
\hline Landscape & & & & & & 1 & 2 & 3 \\
\hline Alumunium + kaca & & & 1 & & 1 & 2 & 1 & 5 \\
\hline Drainase & & & & & & & 1 & 1 \\
\hline Façade & & & & & & 2 & 2 & 4 \\
\hline Waterproof & & & 1 & & & 1 & & 2 \\
\hline Furniture/interior & & & & & 1 & 1 & & 3 \\
\hline Railing tangga & & & & & & I & & 1 \\
\hline \multicolumn{9}{|l|}{ Sipil } \\
\hline Gali tanah & & & & & & $T$ & & 1 \\
\hline Besi & $\mathrm{T}$ & $\mathrm{I}^{-}$ & 3 & 1 & 4 & 14 & 8 & 50 \\
\hline Cor & I & 1 & $\mathrm{r}$ & $\mathrm{i}$ & 3 & 6 & 7 & 28 \\
\hline Bekisting & 1 & 1 & 1 & I & 2 & 3 & 3 & 16 \\
\hline Precast & & & & & 1 & 3 & 1 & 7 \\
\hline Kayu & & & 2 & $\mathrm{~T}$ & 4 & & & 12 \\
\hline Pansang, & & & & & & 2 & 2 & 4 \\
\hline \multicolumn{9}{|l|}{ Mep } \\
\hline Las & $T$ & 1 & & $T$ & 2 & 1 & 1 & 13 \\
\hline Plumbing & & & & & $\mathrm{T}$ & $\mathrm{i}$ & & 4 \\
\hline Arus lemah & 1 & & & & & & & $\mathrm{r}$ \\
\hline Teknisi listrik & 1 & 1 & & & 2 & 2 & 1 & 9 \\
\hline Total & 21 & 14 & 21 & 9 & 52 & 90 & 56 & 272 \\
\hline Mandor & & & 2 & & 6 & 7 & & 22 \\
\hline Wakil mandor & & & $T^{-}$ & & 2 & 3 & & 12 \\
\hline Grand total & 35 & & 37 & & 74 & 160 & & 306 \\
\hline
\end{tabular}

Keterangan: $\mathrm{T}=$ Tukang; $\mathrm{L}=$ Laden

\section{Analisis Data}

Asumsi, Beban biaya pekerja merupakan komponen biaya lain di luar upah, sehingga perhitungan upah dan beban biaya pekerja dilakukan secara terpisah. Perhitungan Upah dan Beban Biaya Pekerja Konstruksi. Proporsi masing-masing komponen beban biaya pekerja terhadap keseluruhan biaya upah akan disajikan pada Tabel 12, Tabel 13, dan Tabel 14. Yang perlu diperhatikan adalah komponen dan tingkat beban biaya pekerja lepas, baik pada tukang, laden, mandor, maupun wakil mandor adalah sama, yaitu hanya terdiri dari APD saja dan berbeda yang ditemui pada PM.

Komponen beban biaya pekerja lepas sama dengan pekerja tetap, namun besarannya berbeda seperti terlihat pada Tabel 11 di bawah ini. ada juga beban biaya pekerja yang bersifat kondisional, misalnya uang transport, uang pulsa, premi asuransi kesehatan, bonus akhir tahun, dan bonus akhir proyek untuk pekerja tetap serta THR untuk tukangdan yang dibayarkan lumpsum seperti: 1) Mes pekerja tetap; 2) Barak pekerja lepas; dan 3) BPJS Ketenagakerjaan pekerja lepas 
Tabel 10. Asumsi perhitungan upah dan beban biaya pekerja

\begin{tabular}{|c|c|c|c|}
\hline \multirow{2}{*}{ No. } & \multirow{2}{*}{ Komponen biava } & \multicolumn{2}{|l|}{ Asumsi } \\
\hline & & Bekeria Tetar & Pckeria Lepas \\
\hline \multicolumn{4}{|c|}{ Upah } \\
\hline 1 & Upahgail & Gais bulanan. & Upah bulanan-upah harian x 54 \\
\hline \multicolumn{4}{|c|}{ Beban biaya eckera } \\
\hline A. & \multicolumn{3}{|l|}{ Lanesuns } \\
\hline \multirow[t]{5}{*}{1} & \multicolumn{3}{|c|}{ Uang makan lebur, dan transport } \\
\hline & - Uang makan & $\begin{array}{l}\text { Uang makan bulanan. } \\
\text { atau } \\
\text { Biaya makan bulanan }=\mathrm{R}_{\mathrm{R}} 65.000,00 \times 25\end{array}$ & $\cdot$ \\
\hline & -Upah lembur & $\begin{array}{l}\text { Upah lembur bulanan }=\text { yang makan }+ \text { ypah lembur } \\
\text { Upah lembgr bulanan }=(\operatorname{Rg} 25.000,00 \times 33)+ \\
\text { upah lembur. }\end{array}$ & $\cdot$ \\
\hline & -Uang, transport & Kondisional & - \\
\hline & -Uang nulsa & Kondisiona & - \\
\hline 2 & \multicolumn{3}{|l|}{ Bonus } \\
\hline & -THR & Minimal gajs pokok 1 balan & - \\
\hline & -Bonus akhic tahur. & Kondisional & - \\
\hline & -Bonus ashir proyek & Kondisional & $\cdot$ \\
\hline B. & \multicolumn{3}{|l|}{ Iidak langsung } \\
\hline \multirow[t]{5}{*}{1} & \multicolumn{3}{|c|}{ Ksssclamatan dan keschatax } \\
\hline & -Seragam keria & Rp 250.000,00 per set & - \\
\hline & $-\mathrm{APD}$ & $\begin{array}{l}\text { helm }=\mathrm{RR}_{2}, 125.000,00 \\
\mathrm{Rompd}=\mathrm{R}_{\mathrm{R}} 50.000,00 \quad \text { Gipakai } 3 \text { tahun } \\
\text { Safery shoes }=\mathrm{R}_{\mathrm{R}} 350.000,00 \\
\text { Masker }=\mathrm{R}_{\mathrm{R}} 5.000,00 \times 4 \times 12=\mathrm{R}_{\mathrm{R}} 240.000,00\end{array}$ & 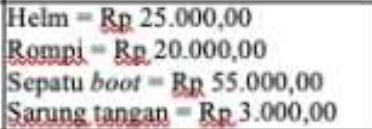 \\
\hline & $\begin{array}{l}\text {-luran bpis } \\
\text { ketenagakstiaan }\end{array}$ & $\begin{array}{l}\text { Iuran bulanan }=11,74 \% \times \text { gail pokok (menikah) } \\
\text { Atau } \\
\text { Iuran bulanan }=8,74 \% \times \text { gaii pokok (laiang) }\end{array}$ & Lumpsum per breyck \\
\hline & -Premi asuransi & Kondisiona & - \\
\hline 2 & Cuts & & \\
\hline & Cuti tahunas. & Cuti tabunan = 12/25 x gail nokok & - \\
\hline & -Cuti melahirkan & Cuti melahirkan $=3 \times$ gait pokok & - \\
\hline & -Cuti sakit & Kondisional & - \\
\hline & $\begin{array}{l}\text {-Suti kencrinan } \\
\text { penting }\end{array}$ & Kondisional & - \\
\hline
\end{tabular}

Tabel 11. Komponen dan proporsi beban biaya pekerja konstruksi terhadap keseluruhan biaya upah

\begin{tabular}{|c|c|c|c|c|c|}
\hline \multirow[t]{2}{*}{ No } & \multirow[t]{2}{*}{ Komponen } & \multicolumn{2}{|c|}{ Pekeria tetap (non PM) } & \multicolumn{2}{|c|}{ Pekeria lepas (tukang dan laden) } \\
\hline & & Besaran (Rp) & Persentase & $\begin{array}{r}\text { Besaran } \\
\text { (RD) }\end{array}$ & Persentase \\
\hline I. & Upah/gaii & 3.510 .021 & $48,33 \%$ & 3.848 .838 & $99,79 \%$ \\
\hline II. & Beban biaya pekeria & 3.752 .868 & $51,67 \%$ & 8.125 & $0,21 \%$ \\
\hline A & Langsung & 2.348 .099 & $32,33 \%$ & & \\
\hline 1 & $\begin{array}{l}\text { Uang makan dan } \\
\text { lembur }\end{array}$ & & & & \\
\hline & - Makan & 817.218 & $11,25 \%$ & & \\
\hline & -Lembur & 1.220 .632 & $16,81 \%$ & & \\
\hline & Bonus & & & & \\
\hline & -THR & 310.249 & $4,27 \%$ & & \\
\hline & Tidak langsung & 1.404 .769 & $19,34 \%$ & 8.125 & $0,21 \%$ \\
\hline & $\begin{array}{l}\text { Keselamatan dan } \\
\text { keschatan }\end{array}$ & & & & \\
\hline & -Scragam keria & 48.039 & $0,66 \%$ & & \\
\hline & -APD & 36.667 & $0,50 \%$ & 8.125 & $0,21 \%$ \\
\hline & $\begin{array}{l}\text {-luran BPJS } \\
\text { ketenagakerjaan }\end{array}$ & 365.079 & $5,03 \%$ & & \\
\hline & Cuti. & & & & \\
\hline & -Cuti tahunan. & 140.401 & $1,93 \%$ & & \\
\hline & -Cuti melahirkan & 814.583 & $11,22 \%$ & & \\
\hline $\mathrm{U}$ & $\begin{array}{l}\text { pah + beban biaya } \\
\text { ckeria }\end{array}$ & 7.262 .889 & $100,00 \%$ & 3.856 .963 & $100,00 \%$ \\
\hline
\end{tabular}


Tabel 12. Komponen dan proporsi beban biaya pekerja konstruksi (pm) terhadap

keseluruhan biaya upah

\begin{tabular}{|c|c|c|c|}
\hline No & Komponen & Besaran (Rp) & Persentase \\
\hline I. & Gaik & 10.400 .000 & $67,20 \%$ \\
\hline II. & Beban biaya pakedia & 5.076 .427 & $32,80 \%$ \\
\hline A. & Langsung & 3.356 .667 & $21,69 \%$ \\
\hline \multirow[t]{3}{*}{1} & Uang makan dan lembur & & \\
\hline & - Makan & 1.500 .000 & $9,69 \%$ \\
\hline & - Lembur. & 990.000 & $6,40 \%$ \\
\hline \multirow[t]{2}{*}{2} & Bonus & & \\
\hline & - THR & 866.667 & $5,60 \%$ \\
\hline $\bar{B}$ & Tidak langsung. & 1.719 .760 & $11,11 \%$ \\
\hline \multirow[t]{4}{*}{1} & Kesselamatan dan keschatan & & \\
\hline & - Seragam keria & 45.833 & $0,30 \%$ \\
\hline & $-A P D$ & 36.667 & $0,24 \%$ \\
\hline & - luran BPJS ketenagakeriaan & 1.221 .260 & $7,89 \%$ \\
\hline \multirow[t]{3}{*}{2} & Cuti & & \\
\hline & - Cuti tahunar. & 416.000 & $2,69 \%$ \\
\hline & Gaji + beban biaya pekeria & 15.476 .427 & $100,00 \%$ \\
\hline
\end{tabular}

Tabel 13. Komponen dan proporsi beban biaya pekerja konstruksi (mandor dan wakilmandor) terhadap keseluruhan biaya upah

\begin{tabular}{|c|l|r|r|r|r|}
\hline \multirow{2}{*}{ No } & \multicolumn{1}{|c|}{ Komponen } & \multicolumn{1}{|c|}{$\begin{array}{c}\text { Mandor } \\
\text { Besaran (Rp) }\end{array}$} & Persentase & Besaran (Rp) & Persentase \\
\hline L. & Upah & 5.334 .091 & $99,85 \%$ & 4.546 .458 & $99,82 \%$ \\
\hline Ii. & Beban biaza pekeria & 8.125 & $0,15 \%$ & 8.125 & $0,18 \%$ \\
\hline A & Tidak langsung & 8.125 & $0,15 \%$ & 8.125 & $0,18 \%$ \\
\hline I & Kesslamatan dan kesebatan & & & & \\
\cline { 1 - 6 } & - APD & 8.125 & $0,15 \%$ & 8.125 & $0,18 \%$ \\
\hline & Upah + beban biaya pekeria & 5.342 .216 & $100,00 \%$ & 4.554 .583 & $100,00 \%$ \\
\hline
\end{tabular}

Identifikasi Variabel, Uji normalitas dan uji homogenitas data perlu dilakukan sebelum menentukan metode yang akan digunakan untuk menganalisis variabel yang mempengaruhi tingkat upah dan beban biaya pekerja konstruksi. Kalau data terdistribusi normal dan homogen, maka dapat dilanjutkan dengan uji parametric (Independent-Samples T test dan One Way ANOVA). Tap ijika salah satu persyaratan uji parametrik tersebut tidak terpenuhi, maka digunakan uji non-parametrik KruskalWallis. Secara singkat, hasil uji analisis pengaruh variabel- variabel independen terhadap variabel dependen terlihat pada Tabel 14.

Salah satu faktor yang tidak berhubungan dengan upah dan beban biaya pekerja adalah pendidikan seperti terihat pada Tabel 14. Beberapa hal yang menyebabkan tidak adanya hubungan antara tingkat pendidikan dengan tingkat upah dan beban biaya pekerjaantara lain: Kelompok jabatan yang kebutuhan kompetensinya rendah, tetap dapat diisi oleh pekerja yang memiliki kompetensi lebih tinggi. Namun tingkat upah dan beban biaya pekerjanya mengikuti kebutuhan kompetensi akan jabatan tersebut. Sebagai contoh pada kelompok jabatan drafter dengan kebutuhan tingkat pendidikan ini adalah SMA/SMK.

Tabel 14. Identifikasi variabel yang berhubungan dengan upah dan beban biaya pekerja konstruksi 


\begin{tabular}{|c|c|c|c|}
\hline \multirow{2}{*}{ Ye } & \multirow{2}{*}{ Yaxiabel indepsaden. } & \multicolumn{2}{|c|}{ Penparubterbadap } \\
\hline & & Cpableaí & Beban biasa pskeria \\
\hline \multicolumn{4}{|c|}{ A. Bekstia tofian } \\
\hline \multicolumn{4}{|c|}{ Dovul Derusatsô. } \\
\hline 1 & Jerix.perusaboan. & & \\
\hline 2 & 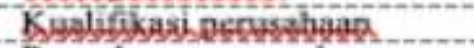 & J & \\
\hline 3 & Bunsalaman nesusstbaan & & \\
\hline \multicolumn{4}{|c|}{ Erotal pooxek } \\
\hline 4 & Kota & $\sqrt{ }$ & $\sqrt{ }$ \\
\hline 5 & Kantor & & \\
\hline 6 & Nilai bogtex. & $\sqrt{2}$ & $\sqrt{2}$ \\
\hline 7 & Distasi preyek. & $\sqrt{ }$ & $\sqrt{2}$ \\
\hline \multicolumn{4}{|c|}{ Exothl pokspes } \\
\hline 8 & Basisi (doatac lapupsin) & & $\sqrt{2}$ \\
\hline 9 & Jabatan & $\sqrt{1}$ & $\sqrt{2}$ \\
\hline 10 & Jecis lselamin. & & \\
\hline 11 & Ysia & $\sqrt{2}$ & \\
\hline 12 & T ingkat pepdidakan. & & \\
\hline 13 & Rengalamar kerab. & $\sqrt{5}$ & $\sqrt{2}$ \\
\hline 14 & Soxtukase & $\sqrt{7}$ & $\sqrt{-7}$ \\
\hline is & Status persikshagh & $\sqrt{2}$ & $\sqrt{2}$ \\
\hline \multicolumn{4}{|c|}{ 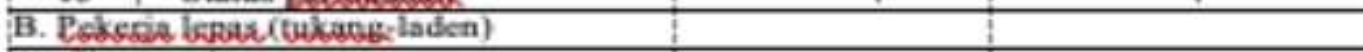 } \\
\hline \multicolumn{4}{|c|}{ Ecotil Depasahasa } \\
\hline I & 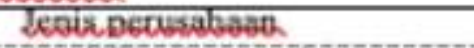 & & \\
\hline 2 & KaAlifikashosusahas & & \\
\hline 3 & Bengalamean peruschiala & & \\
\hline \multicolumn{4}{|c|}{ Expefi nogyck } \\
\hline 4 & Kota & $\sqrt{ }$ & \\
\hline 5 & Kantor & $\sqrt{7}$ & \\
\hline 6 & Nilai kogtrak & I & \\
\hline 7 & Dusarabueysk & & \\
\hline \multicolumn{4}{|c|}{ Bdofilnckenas } \\
\hline 8 & Jabatan & $\sqrt{5}$ & \\
\hline $9^{-}$ & sensisclamin. & & \\
\hline 10 & 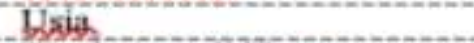 & & \\
\hline ii & Tingkat peodedikao. & & \\
\hline 12 & 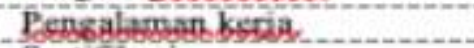 & $\sqrt{2}$ & \\
\hline 13 & Sontukasi & & \\
\hline 14 & Status Deroiksasag. & $\sqrt{2}$ & \\
\hline \multicolumn{4}{|c|}{ 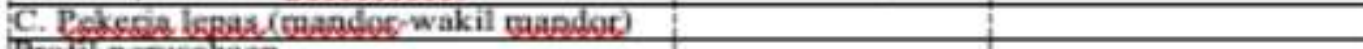 } \\
\hline \multicolumn{4}{|c|}{ Covil DSBusabaara } \\
\hline I & 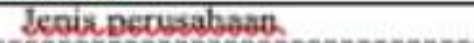 & & \\
\hline 2 & Koalifosab perasaluan. & & \\
\hline 3 & Esmaalamsan pspussobaan & & \\
\hline \multicolumn{4}{|c|}{ Ecotal penusahaara } \\
\hline 4 & Kota & & \\
\hline 5 & Kantor & & \\
\hline 6 & Nilai kegurak & & \\
\hline 7 & Durasipreyek & & \\
\hline \multicolumn{4}{|c|}{ Ecotal potscia } \\
\hline 8 & Jabatas & & \\
\hline 9 & Seciakelamina & & \\
\hline $10^{-}$ & प्रेक्य. & & \\
\hline 11 & Tingkat pendadsar. & & \\
\hline 12 & Pansalamo kepa. & $\sqrt{ }$ & \\
\hline 13 & Sortilukase & & \\
\hline 14 & Status nerrikahusa & & \\
\hline
\end{tabular}

Kenyataannya berdasarkan hasil survei, jabatan ini diisi oleh pekerja dengan tingkat pendidikan D3 dan S1, tapi tingkat upah dan beban biaya pekerjanya mengikuti standar untuk tingkat pendidikan SMA. Ada dua cara untuk mencapai level suatu jabatan, dapat, yaitu melalui tingkat pendidikan atau pengalaman kerja. Misalnya dalam suatu jabatan terdapat responden dengan tingkat pendidikan S1 memiliki 
pengalaman kerja yang lebih rendah dibandingkan dengan yang tingkat pendidikannya SMA. Standar upah dan beban biaya pekerja suatu perusahaan tidak sama dengan perusahaan yang lain. Contoh terdapat responden dengan profil yang sama tapi berbeda tingkat upah dan beban biaya pekerjanya.

Berbeda dengan kelompok pekerja tetap dan kelompok tukang-laden, pada kelompok mandor dan wakil mandor variabel jabatan tidak berhubungan dengan tingkat upah dan beban biaya pekerja.Salah satu penyebabnya adalah wakil mandor hanyalah asisten atau perwakilan dari mandor untuk suatu proyek tertentu karena mandor tersebut tidak hanya bertanggung jawab pada satu proyek saja. Sehingga tingkat upah dan beban biaya pekerja antara mandor dan wakil mandor tidak jauh berbeda.

Salah satu persamaan pekerja tetap dan pekerja lepas adalah variabel kota/kabupaten berhubungan dengan tingkat upah dan beban biayanya. Analisis terhadap variabel kota/kabupatenini dilakukan dengan mempertimbangkan faktor UMR sebagai kelompok data ordinal, di mana kota/kabupaten diurutkan dari nilai UMR yang terkecil. Hasil analisis menggunakan uji Kruskal-Wallis memberikan indikasi bahwa terdapat perbedaan yang signifikan antara rerata upah dan beban biaya pekerja pada kelima kota/kabupaten penelitian. Sehingga, dapat disimpulkan bahwa UMR turut memiliki hubungan dengan tingkat upah dan beban biaya pekerja konstruksi.

\section{Penutup}

Beban biaya pekerja dikelompokkan menjadi biaya secara langsung dan tidak langsung, dan yang bersifat kondisional, tapi distribusi masing-masing komponen biayanya antara pekerja tetap dan pekerja lepas berbeda. Profil perusahaan, profil proyek, dan profilpekerja.berpengaruh pada upah dan beban biaya pekerja konstruksi.

\section{Daftar Pustaka}

Badan Pusat Statistik Nasional, 2019. Benchmark Statistik Konstruksi 2012-2017.

Hedley, George, 2007. Is Your Bid Only an Estimate?. Indianapolis: Associated Construction Publications, LLC.

Huston, Jim, 2004. How to Calculate Labor Burden, J. R. Huston, Inc.

Rabinaw, Steven K., 2006. Prevailing Wage is All The Rage, Thomson Professional and Regulatory Services Inc, Boston.

Soekiman, Anton, dkk., 2011. Study on Factors Affecting Project Level Productivity in Indonesia, Annals of Faculty Engineering Hunedoara- International Journal of Engineering.

Soemardi, B. W., dkk., 2010. Assessing the Role and Competence of Mandor in Indonesian Construction Industry, Second International Conference on Construction in Developing Countries (ICCIDC-II). 29 April 2014.

Soemardi, B.W., Rani Gayatri Kusumawardani. 2010. Studi Praktek Estimasi Biaya Tidak Langsung pada Proyek Konstruksi, Konferensi Nasional Teknik Sipil 4 (KoNTekS 4).

Soemardi, B. W., Teguh L., Santoso, 2005. Kajian Penerapan Outsourcing pada Perusahaan Kontraktor dan Konsultan, Repositori Teknik Sipil Institut Teknologi Bandung, Bandung. 